JH Ius Quia Iustum is licensed under a Creative Commons Attribution 4.0 International License. which permits unrestricted use, distribution, and reproduction in any medium, provided the original work is property cited

\title{
Pergulatan Paham Negara Kesejahteraan (Welfare State) dan Negara Regulasi (Regulatory State) dalam Perkara Konstitusional
}

\author{
Bisariyadi \\ Mahkamah Konstitusi Republik Indonesia \\ Jln. Medan Merdeka Barat No. 6, Jakarta Pusat, 10110 \\ bisariyadi@mahkamahkonstitusi.go.id
}

\begin{abstract}
The concept of Welfare State principally can be applied along with the Regulation State. Welfare refers to the dream of a nation and here carrying out the function of regulatory is a means to achieve it. The alignment of these two concepts is possible. The issue concerned in this study is a debate in the decisions of the Constitutional Court regarding the application to understand the Welfare State and Obligation State in Constitution. The issue is focused on the economic affairs and social welfare, especially in the formation of bodies that have power in ruling as stated in Article 33 and Article 34 of the 1945 Constitution. The issue of this research is regarding the Constitutional Court ruling to dissolve the Executive Agency for Oil and Gas but on the other hand there is the Constitutional Court decision confirming the existence of Social Security Agency. In fact, both are the legal entities established by the state to perform the control and regulation. This research used normative-juridical method and concluded that the Constitution insists on applying the concept of the Welfare State, but it does not mean that there is no space for the development of the concept of Regulation State. Today, granting a ruling authority to certain bodies is inevitable in order to lighten the State burden.
\end{abstract}

Keywords: Constitution court, welfare state, regulation state

Abstrak

Paham negara kesejahteraan sejatinya dapat diterapkan berdampingan dengan negara regulasi. Kesejahteraan adalah impian berbangsa dan menjalankan fungsi pengaturan adalah sarana pencapaiannya. Penyelarasan dua konsep ini bukanlah sesuatu yang tidak mungkin. Permasalahan yang diangkat dalam penelitian ini adalah perdebatan dalam putusan-putusan Mahkamah Konstitusi yang terkait penerapan paham negara kesejahteraan dan negara regulasi dalam konstitusi. Persoalan tersebut dititikberatkan pada urusan ekonomi dan kesejahteraan sosial, terutama dalam pembentukan badan-badan yang memiliki kewenangan di bidang pengaturan sebagaimana diatur dalam Pasal 33 dan Pasal 34 UUD 1945. Permasalahan dalam penelitian ini mengenai putusan Mahkamah Konstitusi yang membubarkan Badan Pelaksana Minyak dan Gas Bumi namun di sisi lain ada juga putusan Mahkamah Konstitusi yang mempertahankan keberadaan Badan Penyelenggara Jaminan Sosial. Padahal keduanya merupakan badan hukum bentukan negara untuk melakukan pengendalian dan pengaturan. Metode penelitian yang digunakan adalah yuridis normatif. Hasil penelitian menyimpulkan bahwa konstitusi menekankan pada penerapan konsep negara kesejahteraan namun tidak berarti bahwa tidak ada ruang gerak bagi pengembangan konsep negara regulasi. Saat ini, pemberian kewenangan pengaturan kepada badan-badan tertentu adalah hal yang tidak dapat dielakkan demi meringankan beban negara.

Kata-kata kunci: Mahkamah konstitusi, negara kesejahteraan, negara regulasi 


\section{Pendahuluan}

UUD 1945 mengamanahkan negara untuk memenuhi kemakmuran rakyat dan menyelenggarakan kesejahteraan sosial dalam satu bagian khusus, yaitu Bab XIV mengenai Perekonomian Nasional dan Kesejahteraan Sosial. Namun, wacana mengenai seberapa besar negara memainkan peranannya dalam konteks ini senantiasa berada dalam ruang perdebatan panjang. Sebagian berpendapat bahwa keterlibatan negara dalam pelaksanaan kedua hal tersebut adalah bersifat langsung (interventionist), sementara sebagian yang lain berpandangan bahwa negara memang memegang peranan dominan tanpa perlu mengambil alih keseluruhan peran tersebut.

Seiring dengan perkembangan global, fungsi negara memang mengalami pergeseran. Sebelumnya, negara dituntut untuk terlibat secara langsung dalam upaya meningkatkan perekonomian nasional serta bertanggungjawab atas kesejahteraan sosial. Pandangan ini didasarkan pada konsep welfare state yang mengacu pada pemikiran yang dilontarkan oleh John Maynard Keynes. ${ }^{1}$ Awal 1990-an, muncul gagasan mengenai negara regulasi (regulatory state) seiring dengan berkembangnya pembentukan lembaga-lembaga negara yang memiliki fungsi pengaturan sesuai dengan lingkup kewenangan yang dimiliki lembaga tersebut. ${ }^{2}$ Istilah negara regulasi sendiri dapat diartikan bahwa konsep ini “...suggests [that] modern states are placing more emphasis on the use of authority, rules and standard-setting, partially displacing an earlier emphasis on public ownership, public subsidies, and directly provided services". ${ }^{3}$ Paling tidak terdapat tiga ciri-ciri model negara regulasi, yaitu (i) birokrasi fungsi pengaturan dipisahkan dari fungsi pelayanan publik; (ii) fungsi pengaturan dipisahkan dari fungsi pembuatan kebijakan sehingga lembaga yang menjalankan fungsi pengaturan dijauhkan dari keterlibatan dalam politik; dan (iii) peraturan dan pembuat peraturan berada pada tahap yang berbeda dari proses pembuat kebijakan. ${ }^{4}$

Model negara regulasi acapkali disebut sebagai pergeseran dari bentuk negara kesejahteraan yang menuntut peran sentral negara untuk memberikan

\footnotetext{
${ }^{1}$ Lihat tulisan Maria Cristina Marcuzzo yang meringkas secara bernas gagasan-gagasan dari Keynes mengenai ekonomi dan tanggung jawab negara. Maria Cristina Marcuzzo. "Keynes and the Welfare State." http://www.ie.ufrj.br/eventos/seminarios/pesquisa/texto_02_12. Pdf, diakses pada 23 September 2016.

2 Giandomenico Majone, "From the Positive State to the Regulatory State: Causes and Consequences of Changes in Modes of Governance", Journal of Public Policy, Vol. 17, May 1997, hlm. 139.

3 David Levi Faur, "Regulation and Regulatory Governance", Working Paper No. 1, February 2010, http://levifaur.wiki.huji.ac.il/images/Reg.pdf, diakses pada 25 September 2016.

4 Ibid, h. 17
} 
kesejahteraan bagi rakyat. Dalam negara kesejahteraan, negara mendominasi peranan dalam pengelolaan seluruh sumber daya sedangkan dalam model negara regulasi negara menitikberatkan peranannya pada produksi regulasi yang akan mengatur kehidupan masyarakat. Pandangan yang menyatakan bahwa negara regulasi merupakan pergeseran dari negara kesejahteraan tidak sepenuhnya disepakati oleh para akademis dan peneliti. Bahwa terdapat perbedaan konsep antara keduanya adalah benar adanya, akan tetapi menyatakan bahwa yang satu merupakan perkembangan dari yang sebelumnya tidaklah semuanya setuju. Konsep negara kesejahteraan adalah mengenai peran yang harus dijalankan negara sedangkan konsep negara regulasi merupakan konsep mengenai unsur-unsur yang dimiliki negara. Keduanya dapat digabungkan dan diharmonisasikan. ${ }^{5}$

Globalisasi memicu kecenderungan untuk menyerahkan segala urusan kepemerintahan pada mekanisme "pasar" (market) dalam rangka meningkatkan efisiensi dan efektivitas. Pelayanan publik seperti di bidang kesehatan, transportasi dan jaminan sosial, yang sedianya diberikan langsung oleh negara, kini diserahkan pada pihak ketiga, yaitu sektor privat. Peran negara adalah dalam hal membuat peraturan dan mengawasi penerapan aturan-aturan yang harus ditaati oleh pihakpihak yang terlibat. Sebagaimana dideskripsikan secara bernas oleh Vogel bahwa "pasar yang lebih bebas menuntut aturan yang lebih ketat". ${ }^{6}$ Oleh karenanya, negara dituntut untuk memproduksi regulasi untuk mengendalikan laju kompetisi yang didasarkan pada mekanisme pasar.

Beberapa ilmuwan politik menyatakan bahwa Indonesia mengarah pada model negara regulasi. ${ }^{7}$ Salah satu indikasinya, negara memproduksi peraturan secara masif, terutama dalam lingkup peraturan daerah. Sisi negatif dari produksi peraturan perundang-undangan yang berlebihan adalah buruknya kualitas materi

5 David Levi-Faur, "The Odyssey of the Regulatory State: Episode One: The Rescue of the Welfare State" Working Paper No 39, November 2011, hlm. 28, http://regulation.huji.ac.il/papers/jp39.pdf. (diakses pada 25 September 2016); lihat juga Hanan Haber, "Regulating-for-Welfare: A Comparative Study of "Regulatory Welfare Regimes" in the Israeli, British, and Swedish Electricity Sectors", Law and Policy, Vol. 33, January 2011, hlm. 116148.

6 Steven Kent Vogel, Freer Markets, More Rules: Regulatory Reform in Advanced Industrial Countries, Cornell University Press, Ithaca, 1996, hlm. 3-4.

7 Stewart Fenwick, Administrative Law and Judicial Review in Indonesia: The Search for Accountability, dalam Tom Ginsburg dan Albert HY Chen (eds), Administrative Law and Governance in Asia: Comparative Perspective, Routledge, New York, 2009, hlm. 352. 
muatan yang terkandung serta banyaknya norma yang tumpang tindih antara satu dengan yang lain. Selaras dengan itu, the Organisation for Economic Co-operation And Development (OECD) dalam laporannya telah menangkap komitmen pemerintah Indonesia untuk menghasilkan produk perundang-undangan yang berkualitas sebagai upaya Indonesia dalam rangka meningkatkan kesejahteraan rakyat dan mempertahankan stabilitas politik dalam negeri. ${ }^{8}$

Judicial review menjadi salah satu jawaban atas persoalan banyaknya peraturan perundang-undangan yang berkualitas rendah. Pengadilan yang memiliki kewenangan judicial review dapat menilai kelayakan peraturan perundang-undangan, dari sisi formal maupun materialnya. ${ }^{9}$ Bahkan tidak jarang pengadilan tidak hanya bertindak sebagai pengawas peraturan (regulatory watchdog) tetapi mengambil peran selangkah lebih maju dengan melakukan pembentukan peraturan. ${ }^{10}$ Selain itu, putusan pengadilan atas perkara judicial review peraturan akan memiliki pengaruh besar terhadap pembentukan peraturan perundang-undangan yang akan disusun berikutnya. ${ }^{11}$

Begitu pula yang terjadi di Indonesia. Putusan perkara judicial review, terutama yang diputus oleh Mahkamah Konstitusi (MK), memiliki pengaruh besar terhadap perubahan kebijakan dan peraturan perundang-undangan. MK memiliki kewenangan untuk melakukan pengujian konstitusionalitas (constitutional review) atas berlakunya UU. Oleh karenanya, perkara yang diperiksa oleh MK disebut juga sebagai perkara konstitusional (constitutional cases). Dalam hirarkhi peraturan perundang-undangan, kedudukan UU tepat berada dibawah UU dengan demikian pengaruh atas pengujian konstitusionalitas UU akan berdampak luas dan signifikan terhadap perubahan kehidupan masyarakat. Selaras dengan itu,

8 OECD adalah organisasi internasional yang memiliki perhatian khusus dalam penyebarluasan gagasan negara regulasi melalui pencanangan dan implementasi program-program yang terkait dengan itu di negara-negara berkembang. OECD, OECD Reviews of Regulatory Reform: Indonesia 2012: Strengthening Co-ordination and Connecting Markets, (OECD Publishing, 2012) h. 65 http://www.keepeek.com/Digital-AssetManagement/oecd/governance/oecd-reviews-of-regulatory-reform-indonesia-2012_9789264173637-en\#.V-

yX_YiLTDc, diakses pada 25 September 20016.

9 David Deller dan Francesca Vantaggiato, "Revisiting the Regulatory State: A Multidisciplinary Review Establishing a New Research Agenda", Centre for Competition Policy Working Paper 14-9, hlm. 12, http://competitionpolicy.ac.uk/documents/8158338/8368036/CCP+Working+Paper+14-9.pdf/6de9dcd30b0f-4c1c-a311-cc472f384653, diakses pada 25 September 2016.

10 Patricia Popelier, "Preliminary Comments on the Role of Courts as Regulatory Watchdogs." Legisprudence, Vol. 6, September 2012, hlm. 257.

${ }^{11}$ Kovacic, W.E., "Economic Regulation and the Courts 1982 to 2001: Ten Cases That Made a Difference", Journal of Regulatory Economics, Vol. 21, January 2002, hlm. 23-34. 
pembahasan utama dalam penelitian ini adalah menyorot pada peran yang dimainkan pengadilan, terutama Mahkamah Konstitusi, dalam model negara regulasi. Dalam bagian pembahasan akan disajikan beberapa putusan MK sebagai studi kasus dengan menekankan pada putusan-putusan pengujian Undangundang yang menafsirkan makna peranan negara dalam bidang perekonomian dan pemenuhan kesejahteraan sosial sebagaimana diatur dalam Pasal 33 dan Pasal 34 UUD 1945. Penafsiran makna konstitusional dari kedua pasal ini memiliki kedudukan strategis karena akan melandasi penyusunan kebijakan dan pengaturan di bidang ekonomi dan kesejahteraan sosial di Indonesia.

Para pakar hukum dan ilmuwan politik belum mencapai kata sepakat apakah Indonesia juga mengadopsi karakteristik negara regulasi. Di sisi lain, tidak ada diantara para ahli yang berbeda pendapat secara tajam bahwa Indonesia sangat kuat menganut paham negara kesejahteraan dimana negara harus terlibat dalam rangka memenuhi kemakmuran dan kesejahteraan rakyatnya. Perbedaannya hanyalah pada seberapa besar porsi negara harus berperan. Dalam beberapa putusan, MK berpendapat bahwa negara harus memiliki peran dominan mewujudkan kemakmuran rakyat dan kesejahteraan sosial. Namun sejauhmana peran yang harus dijalankan negara merupakan pertanyaan yang hingga sekarang belum mendapat jawaban yang pasti, bahkan dari MK sendiri. Oleh karenanya, terbuka ruang perdebatan dimana paham negara kesejahteraan dan karakteristik negara regulasi dianggap sebagai paham yang saling bertentangan ataukah sejatinya kedua konsep ini dapat diterapkan secara bersamaan.

\section{Rumusan Masalah}

Permasalahan dalam penelitian ini adalah bagaimana pendapat Mahkamah Konstitusi mengenai pergulatan wacana penerapan konsep negara kesejahteraan dan negara regulasi?

\section{Tujuan Penelitian}

Tujuan dari penelitian ini adalah untuk mengetahui dan menganalisis pendapat Mahkamah Konstitusi mengenai pergulatan wacana penerapan konsep negara kesejahteraan dan negara regulasi. 


\section{Metode Penelitian}

Penelitian ini menggunakan pendekatan normatif dengan melakukan kajian kepustakaan yang berasal dari sumber data sekunder berupa artikel jurnal ilmiah sebagai bahan referensi. Konsepsi mengenai negara regulasi (regulatory state) tidak banyak dibahas dalam buku maupun artikel ilmiah di Indonesia sehingga laporan dari organisasi internasional seperti the Organisation for Economic Co-operation and Development (OECD) menjadi rujukan pendukung. Pendekatan yang dilakukan adalah melalui studi kasus dengan mempelajari putusan MK. Pembahasan penelitian ini difokuskan pada putusan-putusan pengujian UU yang terkait dengan bidang ekonomi dan kesejahteraan sosial. Dalam bidang ekonomi pembahasan dititikberatkan pada putusan MK dalam perkara pengujian UU Nomor 20 Tahun 2002 tentang Ketenagalistrikan,12 putusan pengujian UU Nomor 7 Tahun 2004 tentang Sumber Daya Air,13 putusan pengujian UU Nomor 22 Tahun 2001 tentang Minyak dan Gas Bumi. ${ }^{14}$ Dalam bidang kesejahteraan sosial, studi kasus difokuskan dengan mempelajari putusan pengujian UU Sistem Jaminan Sosial Nasional ${ }^{15}$ dan putusan pengujian UU Badan Penyelenggara Jaminan Sosial. ${ }^{16}$

\section{Hasil Penelitian dan Pembahasan}

\section{Konstitusionalisme, Negara Kesejahteraan dan Negara Regulasi}

Persoalan ekonomi dan kesejahteraan sosial memiliki perhatian khusus dalam konsepsi negara kesejahteraan dan negara regulasi. Kedua persoalan ini bersinggungan secara langsung dengan konstitusionalisme. Ide konstitusionalisme adalah paham yang membatasi kekuasaan negara dan kedua konsep, baik negara kesejahteraan maupun negara regulasi, memperbincangkan mengenai peranan negara.

12 Putusan Nomor 001-021-022/PUU-I/2003 tentang pengujian Undang-Undang Nomor 20 Tahun 2002 tentang Ketenagalistrikan.

13 Putusan Nomor 058-059-060-063/PUU-II/2004 dan 008/PUU-III/2005 serta Putusan Nomor 85/PUU-XI/2013 mengenai pengujian Undang-undang Republik Indonesia Nomor 7 Tahun 2004 tentang Sumber Daya Air.

14 Putusan Nomor 002/PUU-I/2003 mengenai pengujian Undang-undang Republik Indonesia Nomor 22 Tahun 2001 tentang Minyak Dan Gas Bumi.

15 Putusan Nomor 007/PUU-III/2005 mengenai Pengujian Undang-Undang Republik Indonesia Nomor 40 Tahun 2004 tentang Sistem Jaminan Sosial.

${ }_{16}$ Putusan Nomor 138/PUU-XII/2014 mengenai Pengujian UU Nomor 24 Tahun 2011 tentang Badan Penyelenggara Jaminan Sosial. 
Ketika negara-negara Eropa mengalami pergeseran konseptual menuju negara regulasi, terdapat kendala dalam melakukan harmonisasi antara konstitusionalisme dengan penataan regulasi secara efektif. Konstitusionalisme menuntut penghormatan dan perlindungan hak konstitusional warga negara sedangkan konsep negara regulasi membutuhkan penataan peraturan perundangundangan yang dapat dilaksanakan secara efektif dan efisien. Dengan kata lain, ada tarik menarik antara hak dan peraturan (regulasi).

Sebuah penelitian menunjukkan bahwa hak dan regulasi tidak selamanya saling berlawanan namun dapat berjalan harmonis dengan memanfaatkan faktor kebijakan dan kelembagaan. ${ }^{17}$ Regulasi adalah bagian dari fungsi konstitusi ${ }^{18}$ karena di dalamnya diatur mengenai pembentukan lembaga-lembaga negara dan pengaturan hubungan antara lembaga dan hubungan antar lembaga dengan warga negara. Berangkat dari hal ini juga yang kemudian menciptakan persoalan. Konsep negara regulasi menuntut adanya pembentukan lembaga-lembaga yang memiliki fungsi pengaturan (regulatory agency) yang merupakan turunan dari kewenangan negara. Keberadaan agencyini dianggap tumpang tindih bahkan mereduksi kewenangan organ-organ konstitusional, seperti lembaga legislatif dan utamanya lembaga eksekutif. Persoalan ini berangkat dari sudut pandang sempit akan konstitusionalisme (narrow constitutionalist critique). ${ }^{19}$ Namun, ada pula jenis tantangan lain yang lebih besar (broader constitutionalist challenge) dimana tidak hanya ada regulasi yang dituntut dikeluarkan dari negara tapi juga dari pihak diluar pemerintah yang mengatur mekanisme yang tidak hanya terdapat pada aturan main secara formal. ${ }^{20}$ Oleh karenanya perlu sebuah bentuk ide konstitusionalisme yang tidak hanya negara tetapi juga melibatkan pihak di luar pemerintah serta mekanisme pemerintahan tanpa hanya bergantung pada

\footnotetext{
17 Bronwen Morgan, The Intersection of Rights and Regulation: New Directions in Sociolegal Scholarship, dalam Bronwen Morgan (ed). The Intersection of Rights and Regulation: New Directions in Sociolegal Scholarship, Hampshire, England, and Burlington, Ashgate Publishing, Vermont, 2007, hlm. 19-20.

18 Tony Prosser, Conclusion: Ten Lessons, dalam Dawn Oliver, Tony Prosser, Richard Rawlings (eds), The Regulatory State: Constitutional Implications, Oxford University Press, New York, 2010, hlm. 306-307.

${ }^{19}$ Colin Scott, Regulatory Governance and the Challenge of Constitutionalism, EUI Working Papers 2010, h. 14 http://cadmus.eui.eu/bitstream/handle/1814/13218/ RSCAS_2010_07.pdf;jsessionid= DAA21D8A32BFCA0D13A64A686B6F7FFF?sequence $=1$, diakses 23 September 2016.

${ }^{20}$ Julia Black, "Tension in the Regulatory State", Public Law, Spring, 2007, hlm. 58-73.
} 
negara. ${ }^{21}$ Atau meminjam istilah yang dikemukakan Gunther Teubner, "societal constitutionalism" atau "constitutionalisation without the state". ${ }^{22}$

Hubungan paham konstitusionalisme dan negara kesejahteraan di Indonesia seolah berada pada ranah yang berbeda dengan negara regulasi. Paham negara kesejahteraan mewarnai setiap semangat yang terkandung dalam pengaturan konstitusional, terutama dalam urusan ekonomi dan kesejahteraan sosial. Paham negara kesejahteraan (atau "negara pengurus", dalam bahasa yang digunakan oleh Mohammad Hatta) dipilih oleh para pendiri bangsa (the founding fathers) sebagai dasar didirikannya negara dan bukan negara penjaga malam (nachtwachter staat/night-watchman state). ${ }^{23}$ Begitu juga dalam pandangan Jimly Asshiddiqie yang mengatakan bahwa “... Indonesia adalah negara kesejahteraan (welfare state) yang mengidealkan sifat intervensionisme negara dalam dinamika perekonomian masyarakat, semata-mata untuk kepentingan kesejahteraan masyarakat" ${ }^{24}$ Negara sudah semestinya mengambil alih peran yang berkaitan dengan bidang perekonomian dan kesejahteraan sosial. Model negara kesejahteraan Indonesia memadukan peran ekstensif negara dalam usaha kesejahteraan sosial (universal welfare state) dengan jaminan sosial tersegmentasi disertai jejaring kekeluargaan (social insurance welfare state). ${ }^{25} \mathrm{Hal}$ demikian tercermin dalam pengaturan Pasal 33 dan Pasal 34 UUD 1945. ${ }^{26}$

Pandangan MK mengenai paham negara kesejahteraan juga tercermin dalam putusan-putusan MK yang menafsirkan Pasal 33 dan Pasal 34 UUD 1945. Lalu, dimana keterkaitan model negara regulasi bila urusan perekonomian dan kesejahteraan dikuasai oleh negara? Pembahasan berikut ini mengambil dua kelompok putusan dimana MK menafsirkan Pasal 33 dan Pasal 34 UUD 1945 dengan dikaitkan pada pembentukan badan atau lembaga khusus yang memiliki

${ }^{21}$ Op. Cit., Colin Scott.

22 Gunther Teubner, Societal Constitutionalism: Alternatives to State-Centered Constitutional Theory?, dalam Christian Joerges, Inge-Johanne Sand and Gunther Teubner, (eds.) Constitutionalism And Transnational Governance, Oxford and Portland Oregon: Hart Publishing, 2004, hlm. 3-28.

${ }^{23}$ Sekretariat Negara, Risalah Sidang BPUPKI/PPKI, Jakarta, 1992, hlm. 262; Bandingkan dengan RMAB Kusuma, Labirnya UUD 1945, Badan Penerbit FH UI, Jakarta, 2004, hlm. 355.

${ }^{24}$ Jimly Asshiddiqie, Gagasan Konstitusi Sosial: Institusionalisasi dan Konstistusionalisasi Kehidupan Sosial Masyarakat Madani, Pustaka LP3ES, Jakarta, 2015, hlm. 112.

25 Yudi Latif, Negara Paripurna: Historisitas, Rasionalitas, dan Aktualitas Pancasila, Gramedia Pustaka Utama, Jakarta, 2011, hlm. 582.

26 Ibid. 
kewenangan untuk memproduksi regulasi dan/atau memainkan peran pelayanan secara langsung kepada masyarakat.

\section{Penafsiran MK atas Pasal 33 UUD 1945}

Pasal 33 UUD 1945 merupakan garis kebijakan dasar dalam rangka pengembangan ekonomi kerakyatan demi mewujudkan kesejahteraan sosial. ${ }^{27}$ Ketentuan ini pula, terutama kandungan dalam ayat (2), menjadi bahan utama perdebatan dalam sistem perekonomian yang dianut Indonesia. "Cabang-cabang produksi yang penting bagi negara dan yang menguasai hajat hidup orang banyak dikuasai oleh negara", adalah amanah yang terkandung dalam UUD 1945. Penggalan dari isi pasal tersebut yang menjadi bahan pembahasan adalah mengenai (i) cabang-cabang produksi apa saja yang tergolong sebagai "yang penting bagi negara dan yang menguasai hajat hidup orang banyak"?; (ii) apa batasan dari "dikuasai oleh negara"?

Yang tergolong sebagai cabang produksi sebagaimana dimaksud Pasal 33 ayat (2) UUD 1945 tidak dapat diidentifikasikan secara kaku. Suatu cabang produksi bisa tergolong sebagai yang penting dan menguasai hajat hidup orang banyak disatu saat namun dilain waktu cabang produksi itu bisa berubah. Perkembangan kondisi tiaptiap cabang produksi amatlah dinamis. ${ }^{28}$ Minyak dan Gas Bumi, hari ini bisa dikategorikan sebagai cabang produksi yang penting dan terkait dengan hajat orang banyak tapi dimasa depan Minyak dan Gas Bumi bisa tidak lagi dianggap sebagai cabang produksi yang penting karena keberadaannya telah digantikan dengan sumber energi lainnya. Dengan memperhatikan sifat dinamis dari cabang produksi, MK menyatakan bahwa MK berwenang menguji penilaian yang dibuat oleh pembentuk UU dalam mengkategorikan sesuatu sebagai cabang produksi yang penting bagi negara dan/atau yang menguasai hajat hidup orang banyak..$^{29}$

MK dalam putusan pengujian UU yang berkaitan dengan sumber daya alam (natural resources) memiliki kesatuan pandangan mengenai pengertian frasa "dikuasai oleh negara" dalam Pasal 33 UUD 1945. MK menolak pandangan bahwa

\footnotetext{
${ }^{27}$ Zainal Arifin Hoesein, "Peran Negara dalam Pengembangan Sistem Ekonomi Kerakyatan menurut UUD 1945”, Jurnal Hukum Ius Quia Iustum, No. 3 Vol. 23, Juli 2016, hlm. 525.

${ }^{28}$ Jimly Asshiddiqie, Konstitusi Ekonomi, Kompas, Jakarta, 2010, hlm. 272-278.

29 Putusan Mahkamah Konstitusi Nomor 001-021-022/PUU-I/2003 tentang Pengujian UU Ketenagalistrikan terhadap UUD 1945, hlm. 334-335.
} 
penguasaan oleh negara berarti kepemilikan dalam konsep hukum perdata atau hanya sebatas pengaturan. Penguasaan oleh negara haruslah diartikan sebagai tindakan untuk "(1) merumuskan kebijakan (beleid), (2) melakukan tindakan pengurusan (bestuursdaad), (3) melakukan pengaturan (regelendaad), (4) melakukan pengelolaan (beheersdaad), dan (5) melakukan pengawasan (toezichthoudendaad)" ${ }^{30}$ Kewenangan negara untuk melakukan tindakan-tindakan tersebut adalah kumulatif dan tidak boleh direduksi. Tujuan negara untuk menguasai cabang produksi yang penting adalah demi (i) ketersediaan yang cukup; (ii) distribusi yang merata; dan (iii) terjangkaunya harga bagi banyak orang. ${ }^{31}$

\section{Keberadaan Badan Pelaksana dan Badan Pengatur Minyak dan Gas Bumi}

UU Nomor 22 Tahun 2001 tentang Minyak dan Gas Bumi (UU Migas) memerintahkan pembentukan dua lembaga yang bertugas menangani pengendalian kegiatan usaha hulu, yaitu Badan Pelaksana Hulu Minyak dan Gas Bumi (BP Migas) dan di bidang pengaturan dan pengawasan kegiatan usaha hilir, yaitu Badan Pengatur Hilir Minyak dan Gas Bumi (BPH Migas). Meskipun perintah pembentukan kedua badan tersebut berasal dari UU yang sama namun status "kelembagaan" yang disematkan kepada kedua institusi ini berbeda. UU Migas secara tegas menyebutkan bahwa BP Migas merupakan Badan Hukum Milik Negara (BHMN) ${ }^{32}$ sedangkan terhadap BPH Migas UU tidak menyebutkannya. Bentuk kelembagaan untuk BPH Migas diatur pada Peraturan Pemerintah Nomor 67 tahun 2002 yang menyebutkan bahwa BPH Migas adalah lembaga pemerintah. ${ }^{33}$ Pembedaan konsep antara badan hukum milik negara dengan lembaga pemerintah tidaklah terang benderang. Keduanya merupakan badan hukum publik yang didirikan dengan konstruksi hukum publik melalui peraturan perundangundangan dan memiliki kewenangan di bidang publik dalam arti dapat membuat

30 Putusan Mahkamah Konstitusi Nomor 001-021-022/PUU-I/2003 tentang Pengujian UU Nomor 20 Thaun 2002 tentang Ketenagalistrikan terhadap UUD 1945, hlm. 334; lihat juga Putusan Mahkamah Konstitusi Nomor 002/PUU-I/2003 tentang Pengujian UU Nomor 22 Tahun 2001 Minyak dan Gas Bumi, hlm. 208; dan lihat Putusan Mahkamah Konstitusi Nomor 058-059-060-063/PUU-II/2004 dan Nomor 008/PUU-III/2005 tentang Pengujian UU Nomor 7 Tahun 2004 tentang Sumber daya Air hlm. 498-499.

${ }^{31}$ Putusan Mahkamah Konstitusi Nomor 002/PUU-I/2003 tentang Pengujian UU Nomor 22 Tahun 2001 Minyak dan Gas Bumi, hlm. 330.

32 Pasal 45 ayat (1) UU Nomor 22 Tahun 2001 tentang Minyak dan Gas Bumi.

33 Pasal 2 ayat (2) Peraturan Pemerintah Nomor 67 Tahun 2002 tentang Badan Pengatur Penyediaan Pendistribusian Bahan Bakar Minyak dan Kegiatan Usaha Pengangkutan Gas Bumi Melalui Pipa. 
keputusan atau peraturan yang mengikat umum. Satu hal yang dapat membedakan keduanya adalah dalam kepemilikan aset. Bentuk badan hukum milik negara mengambil konsep seperti BUMN yang memiliki aset yang dipisahkan dari kekayaan negara sedangkan pada lembaga pemerintah aset yang dimiliki adalah bagian dari kekayaan negara.

Keberadaan BP Migas sebagai BHMN masuk dalam jenis statutory body, yaitu badan hukum yang dibentuk berdasarkan peraturan perundang-undangan khusus. ${ }^{34}$ Tujuan pembentukan BP Migas adalah untuk memitigasi tanggung jawab negara ketika terjadi gugatan ganti rugi dari perusahaan kontraktor. Bentuk BP Migas sebagai BHMN tidak lain adalah untuk memisahkan aset negara dengan aset BP Migas sebagai badan hukum sehingga bila terjadi kerugian maka tanggungan atas kerugian tersebut dibatasi pada aset-aset yang dimiliki oleh BP Migas dan tidak terkonsolidasi dengan aset-aset yang dimiliki oleh negara. ${ }^{35}$ Selain itu, BP Migas berperan sebagai wakil dari negara ketika berkontrak dengan perusahaan mitra (rekanan). Negara tidak lagi melakukan penjanjian dengan perusahaan dalam posisi yang setara. Hal ini bertujuan menghindarkan negara dari permasalahan keperdataan yang timbul dari adanya sengketa sekaligus menjaga harga diri dan kehormatan sebagai bangsa bila harus berhadapan dengan perusahaan dalam sengketa keperdataan di forum pengadilan/arbitrase.

Namun, MK berpandangan lain. Ketika keberadaan BP Migas dipertanyakan melalui pengujian konstitusionalitas UU Migas oleh sejumlah pemohon, ${ }^{36} \mathrm{MK}$ menyatakan pertimbangan konstitusionalnya dengan menggunakan parameter penafsiran Pasal 33 UUD 1945. MK berkesimpulan bahwa pendelegasian

\footnotetext{
${ }^{34}$ Contoh lain dari statutory body adalah Undang-Undang Nomor 24 Tahun 2004 tentang Lembaga Penjamin Simpanan. Peraturan perundang-undangan yang digunakan untuk mendirikan atau menetapkan badan hukum oleh negara, tidak hanya dengan UU, tetapi juga bisa dengan peraturan pemerintah (PP), misalnya Peraturan Pemerintah Nomor 152 Tahun 2000 yang menetapkan Universitas Indonesia sebagai Badan Hukum Milik Negara dan PP Nomor 153 Tahun 2000 yang menetapkan Universitas Gajah Mada sebagai Badan Hukum Milik Negara.

${ }^{35}$ Keterangan Ahli Hikmahanto Juwana dalam pemeriksaan persidangan pengujian UU Nomor 22 Tahun 2001 sebagaimana tercantum dalam Putusan Nomor 36/PUU-X/2012 tentang pengujian UU Nomor 22 Tahun 2001 tentang Minyak dan Gas Bumi, hlm. 87.

36 Sejumlah ormas, yang terdiri dari PP Muhammadiyah, Lajnah Siyasiyah Hizbut Tahrir Indonesia, Pimpinan Pusat Persatuan Ummat Islam, Pimpinan Pusat Syarikat Islam Indonesia, Pimpinan Pusat/Lajnah Tanfidziyah Syarikat Islam, Pimpinan Pusat Persaudaraan Muslimin Indonesia, Pimpinan Pusat Al-Irsyad AlIslamiyah, Pimpinan Besar Pemuda Muslimin Indonesia, AL Jami’yatul Washliyah, serta sejumlah tokoh-tokoh yang menyatakan sebagai perorangan warga negara Indonesia mengajukan permohonan Judicial Review UU Nomor 22 Tahun 2001 tentang Minyak dan Gas Bumi ke MK dan didaftarkan sebagai perkara nomor 36/PUU-X/2012.
} 
kewenangan pengelolaan kegiatan usaha hulu migas melalui BP Migas mendegradasi makna sejati penguasaan negara dalam hal perumusan kebijakan, pengurusan, pengaturan, pengelolaan dan pengawasan. Latar belakang pemikiran MK hingga sampai pada kesimpulan tersebut adalah (i) pengelolaan kegiatan usaha hulu migas tidak dilakukan langsung oleh negara (pemerintah); (ii) negara kehilangan kebebasan mengeluarkan regulasi atau kebijakan yang bertentangan dengan Kontrak Kerja Sama yang disepakati antara BP Migas dengan perusahaan kontraktor; dan (iii) keuntungan bagi negara tidak bisa optimal. ${ }^{37}$ Keberadaan BP Migas memperpanjang rentang birokrasi dalam tata kelola migas sehingga fungsi regulasi dan perumusan kebijakan tidaklah efektif. Dalam hal pengelolaan migas, pemerintah harus mengutamakan penguasaan negara pada peringkat pertama yang artinya dikelola langsung oleh negara. ${ }^{38}$ Keberadaan BP migas dalam pengelolaan sektor kegiatan usaha hulu migas dinyatakan inkonstitusional.

Pasca putusan MK, pemerintah bertindak cepat demi mengantisipasi kekhawatiran investor akan nasib kontrak kerja sama yang telah disepakati sebelumnya. Presiden menerbitkan Perpres Nomor 95 Tahun 2012 yang menugaskan Menteri yang menyelenggarakan urusan pemerintahan di bidang minyak dan gas bumi untuk mengambil alih tugas dan fungsi BP Migas. ${ }^{39}$ Sebagai tindak lanjut dari Perpres tersebut, Menteri Energi dan Sumber Daya Mineral (Menteri ESDM) mengeluarkan Keputusan untuk membentuk Satuan Kerja Sementara Pelaksana Kegiatan Usaha Hulu Minyak dan Gas Bumi (SKSP Migas). ${ }^{40}$ Pengambilalihan tugas BP Migas oleh SKSP Migas ini bersifat sementara. Kemudian, untuk menegaskan keberadaan SKSP Migas Presiden menerbitkan Perpres Nomor 9 Tahun 2013.41 Perpres Nomor 9 Tahun 2013 mengubah nama SKSP Migas menjadi satuan kerja khusus pelaksana kegiatan usaha hulu migas (SKK Migas). SKK Migas pada dasarnya hanyalah pergantian nama dari SKSP

\footnotetext{
${ }_{37}$ Putusan Nomor 36/PUU-X/2012 tentang Pengujian UU Nomor 22 Tahun 2001 tentang Minyak dan Gas Bumi, paragraf [3.13.3]

${ }^{38}$ Ibid.

39 Peraturan Presiden Nomor 95 Tahun 2012 tentang Pengalihan Pelaksanaan Tugas dan Fungsi Kegiatan Usaha Hulu Minyak dan Gas Bumi (Lembaran Negara Nomor 226 Tahun 2012)

${ }^{40}$ Surat Keputusan Menteri Energi dan Sumber Daya Mineral Nomor 3135 K/08/MEM/2012 bertanggal 13 November 2012.

41 Peraturan Presiden Nomor 9 Tahun 2013 tentang Penyelenggaraan dan Pengelolaan Kegiatan Hulu Minyak dan Gas Bumi (Lembaran Negara Republik Indonesia Tahun 2013 Nomor 24)
} 
Migas karena tugas, personalia dan aset masihlah sama. ${ }^{42}$ SKK Migas didesain sebagai organisasi yang bersifat sementara sampai adanya revisi UU Nomor 22 Tahun 2001. Namun hingga saat ini belum ada upaya konkret dari pembentuk UU untuk melakukan perubahan UU Nomor 22 Tahun 2001. Selain itu, SKK Migas tetap menjalankan tugas dan fungsinya sebagai pengendali kegiatan usaha hulu migas dengan menjalin kerja sama dengan para pemangku kepentingan seperti melakukan peningkatan kegiatan kerja ulang dan perawatan sumur serta mempertahankan kegiatan eksplorasi dalam hal studi survei dan pengeboran. ${ }^{43}$

Bila SKK Migas, pada dasarnya, hanyalah perubahan nama dari BP Migas maka tata kelola kegiatan usaha hulu migas masih dikelola oleh perpanjangan tangan negara. Padahal Putusan MK mengamanahkan bahwa tata kelola migas seharusnya dikelola langsung oleh negara. Keberadaan SKK Migas pun patut dipertanyakan konstitusionalitasnya.

Kisah yang berbeda terjadi pada BPH Migas. Keberadaan BPH Migas juga diuji konstitusionalitasnya oleh sejumlah pemohon. ${ }^{44}$ Namun, MK berpendapat bahwa BP Migas dan BPH Migas adalah dua institusi yang memiliki tugas dan fungsi yang berbeda. Kegiatan Hulu yang menjadi tanggung jawab BP Migas berkaitan erat dengan hak penguasaan negara. Sedangkan kegiatan hilir migas yang digawangi oleh BPH migas, meskipun memiliki kedudukan yang vital dan strategis namun tidak harus dikuasai oleh negara secara langsung. Pendelegasian kewenangan untuk mengatur dan mengawasi tata kelola kegiatan hilir migas tidaklah perlu dilakukan secara langsung oleh negara selama BPH Migas dapat menjamin distribusi dan ketersediaan Migas dan terselenggaranya kegiatan usaha hilir melalui mekanisme persaingan usaha yang wajar, sehat, dan transparan. ${ }^{45}$

Pembentukan kedua institusi ini, BP Migas dan BPH Migas, merupakan ciri penerapan regulatory governance. Negara tidak lagi campur tangan secara langsung

${ }^{42}$ Dian Aries Mujiburohman, “Akibat Hukum Pembubaran BP Migas”, Mimbar Hukum, Vol. 25, Oktober 2013, hlm. 473.

43 “Laporan Tahunan SKK Migas Tahun 2015", http://www.skkmigas.go.id/wpcontent/uploads/2013/06/LAPORAN-TAHUNAN-SKK-MIGAS-2015.pdf, diakses 27 September 2016.

${ }^{44}$ Federasi Serikat Pekerja Pertamina Bersatu (FSPPB) dan Konfederasi Serikat Pekerja Migas Indonesia (KSPMI) mengajukan permohonan pengujian UU Nomor 22 Tahun 2001 yang diregistrasi dengan Perkara Nomor 65/PUU-X/2012.

45 Putusan Mahkamah Konstitusi Nomor 65/PUU-X/2012 tentang Pengujian UU Nomor 22 Tahun 2001 tentang Minyak dan Gas Bumi, paragraf [3.11.2] 
dalam tata kelola migas namun mendelegasikan kewenangan pengaturan (regulasi) kepada lembaga independen berupa BHMN. Namun batas pendelegasian kewenangan tersebut untuk sektor kegiatan usaha hulu migas oleh MK dinilai inkonstitusional. MK berpendapat bahwa pemberian kewenangan kepada lembaga independen mendegradasi kewenangan negara dalam hak penguasaan negara. Berbeda halnya dengan keberadaan BPH migas yang mengelola kegiatan usaha hilir migas dimana lingkup hak penguasaan negara tidak sampai pada kegiatan usaha hilir.

\section{Penafsiran MK atas Pasal 34 UUD 1945}

Ketika dihadapkan pada pengujian konstitusionalitas UU Nomor 40 Tahun 2004 tentang Sistem Jaminan Sosial Nasional (UU SJSN), MK berkesempatan untuk memberikan tafsir atas Pasal 34 UUD 1945. Merujuk pada latar belakang sejarah penyusunan UUD 1945, MK berpendapat bahwa semangat yang terkandung dalam Pasal 34 didasari pemikiran paham negara kesejahteraan. ${ }^{46}$ Paham ini mewajibkan negara bertanggungjawab dalam urusan kesejahteraan rakyatnya, yang di dalamnya termasuk fungsi negara untuk mengembangkan jaminan sosial. Paham negara kesejahteraan ini makin ditegaskan oleh Majelis Permusyawaratan Rakyat (MPR) ketika melakukan Perubahan Pasal 34 UUD 1945. Pasal 34 ayat (2) UUD 1945 menyatakan bahwa "Negara mengembangkan sistem jaminan sosial bagi seluruh rakyat dan memberdayakan masyarakat lemah dan tidak mampu sesuai dengan martabat kemanusiaan". Ada dua kriteria konstitusional penerapan sistem jaminan sosial, yaitu diterapkan bagi seluruh rakyat (komprehensif) dan pemberdayaan masyarakat tidak mampu. Kedua kriteria ini membuat model negara kesejahteraan Indonesia menjadi unik dan disebut sebagai paham welfare state terbuka. ${ }^{47}$

\section{Keberadaan Badan Penyelenggara Jaminan Sosial}

Konsep jaminan sosial Indonesia menerapkan prinsip gotong royong dimana orang yang memenuhi syarat diwajibkan untuk menjadi peserta asuransi dengan

\footnotetext{
46 Putusan Mahkamah Konstitusi Nomor 007/PUU-III/2005 tentang Pengujian UU Nomor 40 Tahun 2004 tentang Sistem Jaminan Sosial Nasional, hlm. 263.

47 Alfitri, "Ideologi Welfare State dalam Dasar Negara Indonesia: Analisis Putusan Mahkamah Konstitusi Terkait Sistem Jaminan Sosial Nasional”, Jurnal Konstitusi, Vol. 9, September 2012, hlm. 466-467.
} 
kewajiban membayar premi sedangkan pemerintah memberikan subsidi dalam pembayaran premi bagi masyarakat yang tidak mampu. Semangat gotong royong ini tercermin dalam pendapat MK ketika memutus pengujian UU Nomor 24 Tahun 2011 tentang Badan Penyelenggara Jaminan Sosial (UU BPJS). Pemohon beranggapan bahwa negara telah bertindak sewenang-wenang dengan memaksa pemungutan upah dari pekerja sebagai iuran BPJS. MK berpendapat bahwa mewajibkan penduduk untuk ikut serta dalam asuransi sosial adalah dalam rangka pemenuhan hak konstitusional warga negara melalui pembiayaan secara kolektif yang mengutamakan kepentingan bersama. ${ }^{48}$ Selain itu, kewajiban membayar iuran secara proporsional akan menciptakan subsidi silang dimana pekerja dengan upah kecil akan membayar iuran dengan nominal yang kecil tetapi jaminan layanan medis ketika sakit tidak dibedakan berdasarkan pembayaran iurannya. ${ }^{49}$

Sejak 1 Januari 2014, Indonesia memulai proyek ambisius dengan target mencapai cakupan universal kesehatan (Universal Health Coverage) untuk seluruh rakyat pada 2019. Pada 2013, 76\% penduduk Indonesia terlindungi oleh skema asuransi dengan model yang berbeda-beda, baik melalui oleh perusahaan milik pemerintah maupun pemerintah daerah, seperti Jaminan Kesehatan Masyarakat (Jamkesmas), Jaminan Kesehatan Daerah (Jamkesda), Asuransi Kesehatan (Askes) bagi Pegawai Negeri, Jaminan Pelayanan Kesehatan (JPK) Jamsostek. ${ }^{50}$ Seluruh skema asuransi kesehatan dan ketenagakerjaan akan dipusatkan dalam satu badan dengan pembentukan BPJS. Tantangan utama dalam memperluas cakupan adalah (i) untuk memastikan bahwa 40 persen masyarakat paling miskin sesuai rencana dijamin pembiayaannya oleh pemerintah pusat; dan (ii) untuk memperluas pengumpulan kontribusi dari pekerja informal yang tidak miskin. ${ }^{51}$ Selain itu,

48 Putusan Mahkamah Konstitusi Nomor 138/PUU-XII/2014 tentang Pengujian UU nomor 24 Tahun 2011 tentang Badan Penyelenggara Jaminan Sosial, Paragraf [3.11]

${ }^{49}$ Ibid.

${ }^{50}$ Lihat Kementerian Kesehatan, "Profil Kesehatan Indonesia Tahun 2013", Lampiran 4.4. Cakupan Kepesertaan Jaminan Kesehatan Tahun 2013, http://www.depkes.go.id/resources/download/pusdatin/profilkesehatan-indonesia/profil-kesehatan-indonesia-2013.pdf (diakses pada 27 September 2017), lihat juga rincian data peserta asuransi yang dikelola oleh swata maupun pemerintah, Nafsiah Mboi, "Moving Towards Universal Health Access in Indonesia", http://luk.staff.ugm.ac.id/atur/bpjs/ HealthAccessInIndonesia-2013Dec11HarvardClub101213.pptx, diakses 27 September 2016

51 The World Bank, "Perkembangan Triwulanan Perekonomian Indonesia, membawa Perubahan", Desember 2014, hlm. 43 http://www.worldbank.org/content/dam/Worldbank/ document/EAP/ Indonesia/IEQ-DEC-2014-bh.pdf, diakses 28 September 2016. 
kesiapan pelayanan kesehatan umum untuk menyediakan pelayanan kesehatan dasar yang sesuai dengan standar minimum, ditemukan variasi yang sangat tinggi antar provinsi, dengan kesiapan rendah di beberapa provinsi di bagian timur seperti Papua, Maluku, Papua Barat, Sulawesi Barat dan Maluku Utara. ${ }^{52}$ Oleh karenanya, formulasi kebijakan integrasi jaminan kesehatan tingkat daerah diperlukan keseimbangan antara peran pemerintah pusat dan daerah. Kebijakan ini bukan sebatas melakukan sentralisasi seluruh sistem yang ada kedalam sistem yang lebih besar, tetapi juga harus seimbang dalam menjaga kesinambungan semangat desentralisasi dan kepentingan masyarakat. ${ }^{53}$

Selaras dengan itu, MK berpendapat bahwa kata "negara" dalam Pasal 34 ayat (2) UUD 1945 juga mencakup peran serta pemerintah, pemerintah daerah dan pihak swasta untuk turut serta mengembangkan sistem jaminan sosial dengan cara menyediakan fasilitas kesehatan untuk masyarakat. ${ }^{44}$ Kata "mengembangkan" yang digunakan dalam Pasal 34 ayat (2) UUD 1945 berarti bahwa tanggung jawab negara dalam rangka memenuhi hak warga negara atas jaminan sosial adalah sebatas "membuat sistem jaminan sosial yang telah ada menjadi lebih besar atau lebih maju", sesuai dengan pemaknaan kata menurut Kamus Besar Bahasa Indonesia (KBBI). ${ }^{55}$ Negara dalam memenuhi hak atas jaminan sosial warga negara tidak memiliki kewajiban untuk menyelenggarakan sistem jaminan sosial secara langsung layaknya dalam penyelenggaraan pendidikan. Oleh karena itu, BPJS juga harus membuka diri untuk bersinergi dengan pihak swasta dalam mewujudkan jaminan sosial bagi seluruh rakyat Indonesia. Inilah model negara kesejahteraan terbuka Indonesia dimana negara juga melibatkan pihak swasta untuk terlibat dalam penyelenggaraan sistem jaminan sosial.

Perubahan sistem jaminan sosial dengan menyatukan semua Badan Usaha Milik Negara (BUMN) penyelenggara menjadi satu badan hukum publik yang dibentuk khusus bertujuan agar jaminan sosial dapat mencakup seluruh rakyat

${ }^{52}$ Ibid., hlm. 45

53 Supriyantoro, "Formulasi Kebijakan Integrasi Jaminan Kesehatan Daerah ke Sistem Jaminan Kesehatan Nasional menuju Universal Health Coverage", Disertasi pada Fakultas Kedokteran Universitas Gadjah Mada di tahun 2014, hlm. 62

54 Putusan Mahkamah Konstitusi Nomor 138/PUU-XII/2014 tentang Pengujian UU Nomor 24 Tahun 2011 tentang Badan Penyelenggara Jaminan Sosial, hlm. 205

${ }^{55}$ Ibid., hlm. 201. 
dan mampu untuk meningkatkan keberdayaan masyarakat yang lemah. Hal ini selaras dengan pertimbangan MK dalam putusan sebelumnya yang berpendapat bahwa "...sistem apa pun yang dipilih dalam pengembangan jaminan sosial tersebut harus dianggap konstitusional, ...sepanjang sistem tersebut mencakup seluruh rakyat dan dimaksudkan untuk meningkatkan keberdayaan masyarakat yang lemah dan tidak mampu sesuai dengan martabat kemanusiaan".56 Penyerahan sistem jaminan sosial kepada BPJS meluruskan kembali tujuan jaminan sosial yang hanya menyelenggarakan program jaminan sosial dengan prinsip gotong-royong, nirlaba, dan tata kelola yang baik (good governance).

\section{Penutup}

Ketika menguji konstitusionalitas UU Migas dalam rangka menilai pembentukan BP Migas, MK berkesimpulan bahwa dalam urusan pengelolaan kegiatan usaha hulu migas kedudukan negara tidak dapat diwakili. Negara harus melakukan fungsi perumusan kebijakan, pengurusan, pengaturan, pengelolaan dan pengawasan secara langsung. Fungsi-fungsi tersebut merupakan tafsiran dari hak menguasai negara sebagaimana diatur Pasal 33 UUD 1945. Sumber daya alam harus di kelola secara langsung oleh negara sebagai bentuk penguasaan dalam peringkat pertama. Namun prakteknya, pemerintah tetap mempertahankan adanya regulatory agency dalam tata kelola minyak dan gas bumi untuk kegiatan usaha hulu migas dengan nama lembaga yang berbeda dan dasar hukum pembentukannya tidak didasari pada UU, melainkan melalui Peraturan Presiden.

Dalam hal pembentukan BPJS, MK memiliki pandangan lain, bahwa BPJS merupakan regulatory agency yang memiliki kewenangan mengatur sekaligus memberikan pelayanan jaminan sosial bagi seluruh rakyat Indonesia. Campur tangan negara dalam penyelenggaraan sistem jaminan sosial dapat dilaksanakan oleh pemerintah dan pemerintah daerah namun dapat juga diwakili oleh badan hukum bentukan negara seperti BPJS. Hal demikian tidak mengurangi esensi negara kesejahteraan yang dimandatkan oleh Konstitusi. UUD 1945 memberi penekanan pada penerapan konsep negara kesejahteraan melalui dominasi keterlibatan negara

56 Putusan Nomor 50/PUU-VIII/2010, Para [3.14.3] 
dalam rangka mewujudkan kemakmuran sebesar-besarnya bagi rakyat. Namun, bukan berarti tidak ada ruang bagi konsep negara regulasi untuk berkembang. Negara tidak dapat selamanya mendominasi peran dan turut campur tangan dalam segala urusan yang menyangkut kehidupan rakyat. Ada kalanya dimana negara perlu mengambil langkah sedikit kebelakang dengan menjadi pengawas dan pengatur melalui pembentukan peraturan perundang-undangan dan menyerahkan kegiatan-kegiatan yang tidak termasuk dalam kategori penting dan menguasai hajat hidup orang banyak pada lembaga independen.

\section{Daftar Pustaka}

\section{Buku}

Asshiddiqie, Jimly, Gagasan Konstitusi Sosial: Institusionalisasi dan Konstistusionalisasi Kehidupan Sosial Masyarakat Madani, Pustaka LP3ES, Jakarta, 2015. , Konstitusi Ekonomi, Kompas, Jakarta, 2010.

Fenwick, Stewart, Administrative Law and Judicial Review in Indonesia: The Search for Accountability, dalam Tom Ginsburg dan Albert HY Chen (eds), Administrative Law and Governance in Asia: Comparative Perspective, Routledge, New York, 2009

Kusuma, RMAB, Lahirnya UUD 1945, Badan Penerbit FHUI, Jakarta, 2004.

Latif, Yudi, Negara Paripurna: Historisitas, Rasionalitas, dan Aktualitas Pancasila, Gramedia Pustaka Utama, Jakarta, 2011.

Prosser, Tony, Conclusion: Ten Lessons, dalam Dawn Oliver, Tony Prosser, Richard Rawlings (eds), The Regulatory State: Constitutional Implications, Oxford University Press, New York, 2010.

Tate, C. Neal, Comparative judicial Review and Public Policy: Concepts and Overview, dalam Donald W.Jackson \& C. Neal Tate (eds.), Comparative Judicial Review and Public Policy, Greenwood Press, London, 1992.

Teubner, Gunther, Societal Constitutionalism: Alternatives to State-Centered Constitutional Theory?, dalam Christian Joerges, Inge-Johanne Sand and Gunther Teubner, (eds.) Constitutionalism And Transnational Governance, Hart Publishing, Oxford and Portland Oregon, 2004.

Vogel, Steven Kent, Freer Markets, More Rules: Regulatory Reform in Advanced Industrial Countries. Cornell University Press, Ithaca, 1996.

\section{Jurnal}

Alfitri, "Ideologi Welfare State dalam dasar Negara Indonesia: Analisis Putusan Mahkamah Konstitusi Terkait Sistem Jaminan Sosial Nasional", Jurnal Konstitusi, Vol. 9, September 2012. 
Ali, Mohammad Mahrus; Hilipito, Meyrinda Rahmawaty; dan Asy'ari, Syukri, “Tindak Lanjut Putusan Mahkamah Konstitusi yang Bersifat Konstitutional Bersyarat Serta Memuat Norma Baru", Jurnal Konstitusi, Vol. 12, September 2015

Bisariyadi, "Atypical Rulings of the Indonesian Constitutional Court", Hasanuddin Law Review, Vol. 2, August 2016.

de Andrade, Gustavo Fernandes, "Essay: Comparative Constitutional Law: Judicial Review", University of Pennsylvania Journal of Constitutional Law, Vol. 3, May 2001.

Ferejohn, John E., "Constitutional Review in the Global Context", New York University Journal of Legislation and Public Policy, Vol. 6, January 2002.

Ginsburg, Tom \& Versteeg, Mila, "Why Do Countries Adopt Constitutional Review?," Journal of Law, Economics and Organization, Vol. 30, August 2014.

Haber, Hanan, "Regulating-for-Welfare: A Comparative Study of "Regulatory Welfare Regimes" in the Israeli, British, and Swedish Electricity Sectors", Law and Policy, Vol. 33, January 2011.

Hoesein, Zainal Arifin, "Peran Negara dalam Pengembangan Sistem Ekonomi Kerakyatan menurut UUD 1945", Jurnal Ius Quia Iustum, Vol. 23, Juli 2016.

Kovacic, W.E., “Economic Regulation and the Courts 1982 to 2001: Ten Cases That Made a Difference", Journal of Regulatory Economics, Vol. 21, January 2002.

Majone, Giandomenico, "From the Positive State to the Regulatory State: Causes and Consequences of Changes in Modes of Governance", Journal of Public Policy, Vol. 17, May 1997.

Mujiburohman, Dian Aries, "Akibat Hukum Pembubaran BP Migas", Mimbar Hukum, Vol. 25, Oktober 2013.

Popelier, Patricia, "Preliminary Comments on the Role of Courts as Regulatory Watchdogs." Legisprudence, Vol. 6, September 2012.

Supriyantoro, "Formulasi Kebijakan Integrasi Jaminan Kesehatan Daerah ke sistem jaminan Kesehatan Nasional menuju Universal Health Coverage", Disertasi pada Fakultas Kedokteran Universitas Gadjah Mada di tahun 2014

\section{Putusan Pengadilan}

Peraturan Presiden Nomor 9 Tahun 2013 tentang Penyelenggaraan dan Pengelolaan Kegiatan Hulu Minyak dan Gas Bumi (Lembaran Negara Tahun 2013 Nomor 24)

Peraturan Presiden Nomor 95 Tahun 2012 tentang Pengalihan Pelaksanaan Tugas dan Fungsi Kegiatan Usaha Hulu Minyak dan Gas Bumi (Lembaran Negara Nomor 226 tahun 2012) 
Surat Keputusan Menteri Energi dan Sumber Daya Mineral Nomor 3135 K/08/MEM/2012 bertanggal 13 November 2012

\section{Peraturan Perundang-undangan}

Marbury v. Madison, 5 U.S. 137, (1803)

Putusan Mahkamah Konstitusi Nomor 001-021-022/PUU-I/2003 tentang Pengujian UU Nomor 20 Tahun 2002 tentang Ketenagalistrikan.

Putusan Mahkamah Konstitusi Nomor 002/PUU-I/2003 tentang Pengujian UU nomor 22 tahun 2001 Minyak dan Gas Bumi.

Putusan Mahkamah Konstitusi Nomor 007/PUU-III/2005 tentang Pengujian UU Nomor 40 Tahun 2004 tentang Sistem Jaminan Sosial Nasional.

Putusan Mahkamah Konstitusi Nomor 058-059-060-063/PUU-II/2004 dan Nomor 008/PUU-III/2005 tentang Pengujian UU Nomor 7 Tahun 2004 tentang Sumber Daya Air.

Putusan Mahkamah Konstitusi Nomor 138/PUU-XII/2014 tentang Pengujian UU Nomor 24 Tahun 2011 tentang Badan Penyelenggara Jaminan Sosial

Putusan Mahkamah Konstitusi Nomor 36/PUU-X/2012 tentang pengujian UU Nomor 22 Tahun 2001 tentang Minyak dan Gas Bumi.

Putusan Mahkamah Konstitusi Nomor 65/PUU-X/2012 tentang Pengujian UU Nomor 22 Tahun 2001 tentang Minyak dan Gas Bumi

\section{Internet}

Deller, David dan Vantaggiato, Francesca, "Revisiting the Regulatory State: A Multidisciplinary Review Establishing a New Research Agenda", Centre for Competition Policy Working Paper 14-9, http://competitionpolicy.ac.uk/ documents /8158338/8368036/CCP+Working+Paper+14-9.pdf/6de9dcd30b0f-4c1c-a311-cc472f384653, diakses tanggal 25 September 2016

Kementerian Kesehatan, "Profil Kesehatan Indonesia Tahun 2013", http:/ / www.depkes.go.id/resources/download/pusdatin/profil-

kesehatan-indonesia/profil-kesehatan-indonesia-2013.pdf, diakses tanggal 27 September 2016

Laporan Tahunan Mahkamah Agung Tahun 2015, diunduh http:/ / www.pembaruanperadilan.net/v2/content/publikasi/LTMARI\% 20-\%202015.pdf, diakses tanggal 22 September 2016

Laporan Tahunan SKK Migas Tahun 2015, http://www.skkmigas.go.id/wpcontent/uploads / 2013/06/LAPORAN-TAHUNAN-SKK-MIGAS2015.pdf, diakses tanggal 27 September 2016

Levi-Faur, David, "Regulation and Regulatory Governance", Working Paper No. 1 February 2010, http://levifaur.wiki.huji.ac.il/images/Reg.pdf, diakses tanggal 25 September 2016 
"The Odyssey of the Regulatory State: Episode One: The Rescue of the Welfare State" Working Paper No 39, November 2011, http://regulation.huji.ac.il/papers/jp39.pdf., diakses tanggal 25 September 2016

Marcuzzo, Maria Cristina, "Keynes and the Welfare State." http:/ /www.ie.ufrj.br/ eventos/seminarios/pesquisa/texto_02_12.pdf., diakses pada 23 September 2016

Mboi, Nafsiah, "Moving Towards Universal Health Access in Indonesia", http:/ /luk.staff.ugm.ac.id/atur/bpjs/HealthAccessInIndonesia2013Dec11-HarvardClub101213.pptx, diakses tanggal 27 September 2016

OECD, OECD Reviews of Regulatory Reform: Indonesia 2012: Strengthening Coordination and Connecting Markets, (OECD Publishing, 2012) http:/ / www.keepeek.com/Digital-Asset-

Management/oecd/governance/oecd-reviews-of-regulatory-reformindonesia-2012_9789264173637-en\#.V-yX_YiLTDc, diakses tanggal 25 September 2016

Rose-Ackerman, Susan, "Judicial Review Of Executive Policymaking In Advanced Democracies: Beyond Rights Review", Faculty Scholarship Series Paper 4943 (2014)

http:/ / digitalcommons.law.yale.edu/cgi/viewcontent.cgi?article=5955\&c ontext=fss_papers, diakses tanggal 25 September 2016

Scott, Colin, Regulatory Governance and the Challenge of Constitutionalism, EUI Working Papers 2010, http://cadmus.eui.eu/bitstream/handle/1814/13218/RSCAS_2010_07.p df;jsessionid $=$ DAA21D8A32BFCA0D13A64A686B6F7FFF?sequence $=1$, diakses tanggal 23 September 2016

The World Bank, "Perkembangan Triwulanan Perekonomian Indonesia, membawa Perubahan", Desember 2014, http://www.worldbank.org/content/dam/Worldbank/document/EAP /Indonesia/ IEQ-DEC-2014-bh.pdf, diakses tanggal 28 September 2016 